\title{
Using an Online Self-regulation Based Vocabulary Learning Program to Improve Secondary Stage EFL Students Reading Comprehension
}

\author{
Wafa``Alam Eldeen Abd Elsalam
}

\begin{abstract}
The purpose of the present study was to investigate using an online selfregulation based vocabulary learning program to improve secondary stage EFL students reading comprehension. To fulfill the purpose of the study, four instruments were constructed; an Online Reading Comprehension Skills Questionnaire was designed to determine reading comprehension -skills that EFL secondary stage students need, a Pre-post Online Reading Comprehension Test, an Online Vocabulary Strategies Inventory, and an Online Self regulation Strategies Scale. The validity and reliability of the study instruments were established before their use in the study. The study adopted the quasi-experimental design. The sample of the study consisted of 60 EFL first grade secondary stage students. They were randomly selected from Bahbeet Alhegara Secondaray Scool at Samanoud Educational Zone in Gharbia where 30 student represented the experimental group and 30 represented the control group. The online self regulation based vocabulary learning program was administered to the experimental group for 8 weeks whereas the control group received the conventional teaching. Results of the study revealed that online self regulation based vocabulary learning program led to significant improvement in first grade secondary stage student EFL online reading comprehension skills. A number of recommendations concerning the use self regulation strategy training, vocabulary strategy training, and online reading comprehension were presented.
\end{abstract}

Key words: Online Program, Reading Comprehension, Self regulation Strategy, Vocabulary Strategy.

\section{Introduction}

Reading is an active skill that involves an interaction between the reader and the text. The importance of reading lies into its crucial role for the language leaner to gain the printed knowledge or information (Woolley, 2011).There's also an equal importance of teaching reading comprehension inside classroom for the academic success as well as teaching comprehension outside schools. The need of preparing autonomous learners in and outside school and the opportunities for these students to succeed has been increased (James, 2012).

More and more reading improves the person's reading skill. And, as the reader face content and new material, his vocabulary stock is increased. Through reading, the foreign language learner can command 
his foreign language mastery because he encounters and sees how new vocabulary are used naturally in writing (John, 2004). Reading comprehension is affected mainly by vocabulary knowledge beside many other factors such as ; illiteracy, activating background knowledge and the use of various reading skills e.g. summarizing, identifying the main idea, and distinguishing between fact and opinion (Constantinescu, 2007).

Many studies asserted the positive relationship between students' vocabulary knowledge and reading comprehension because foreign language learners seem to rely more in word meaning than knowledge of the subject or syntax. Moreover, in order to comprehend a text, readers should be familiar with 95 percent of the words in the text at any level. The bottom line for reading English at an academic level is 3000 words, or 5000 lexical units (Korens, 1999). Therefore, instruction of basic vocabulary has been a basic component of any teacher reading program (Fleet, 1991).

One of the learner self directed variables for vocabulary learning is self regulation. Many researchers assured the role of self regulation in facilitating vocabulary acquisition namely by developing self regulation strategies. Self regulation strategies enable learners not only to acquire a large number of words but to recall and cope with any gap. This relation could be interpreted in the light of retention. (Hamedani, 2013).
Self regulation strategies are very important for helping readers to interpret meaning from written text which leads for creation of autonomous reader (Davis \& Gray, 2004). More skilled readers employ a broad range of strategies appropriate for various processes and stages of reading. In addition, self regulated readers set up realistic goals, monitor his progress, and appreciate the results (Chen, 2009).

In this age, technology could not be apart of daily instruction in schools especially for EFL learners. One advantage of using technology is facing students diversity of needs especially while performing in lexical tasks. This is because it can adapt students` outside-of-school knowledge and interests. Connecting home with school while dealing with literary skills is a very hard task. Online treatments can overcome this obstacle easily (Clark, 2013).

Although teaching online vocabulary strategies acquired importance in improving students' reading skills, it is very beneficial for EFL teachers to instruct these strategies through self regulation model. One of the most comprehensive models is Pinitrich model which is characterized by explicitness of self regulation strategies through the four phases. Therefore, the current study investigates training EFL secondary stage students in using some vocabulary strategies online to improve their reading comprehension skills through Pintrich self-regulation model. 


\section{Review of literature \\ Reading Comprehension}

Reading is a process that includes both psycholinguistic and sociolinguistic processes. Because many cognitive operations are included, reading is considered a psycholinguistic process. Moreover, reading is considered a sociolinguistic process because many social related factors are involved that affect what one reads, how one reads, and how much one understand from reading (Elangovan \& Chia, 2013).

Mohamed (2010) investigated the effects of a suggested computer strategy training program on developing EFL preparatory school pupils' reading comprehension in Egypt. The researcher administrated a pre reading comprehension test according a suggested EFL reading comprehension skills on two experimental groups and on a control group. The first experimental group studied by the computer strategy training program, while the second experimental group studied by the strategy training program without the use of computer. The control group studied the same course through the traditional method. Intervention lasted for three months. Results showed that the first experimental group exceeded both the second experimental group and the control group. Also, the second experimental group significantly outperformed the control group.

Lenhard et al. (2011) implemented two different strategy training programs in nine classes of Grade 6 students ("N" = 148) in Germany over the course of one school year. One program involved teacherdirected instruction of declarative meta-cognitive knowledge. The other aimed at improving executive metacognition by guided practice: students worked with a computer program based on latent semantic analysis (LSA) ("conText") and received immediate feedback on written summaries. Although both groups improved their strategy knowledge to the same extent, the "conText" group showed a greater improvement in reading comprehension. These findings suggested that guided practice, which is characterized by intensive practice and individualized corrective feedback, is superior to explicitly teaching strategy knowledge.

Huang (2014) investigated the effectiveness of online versus paperbased reading strategy instruction on EFL learners' reading comprehension. Fifty-seven university students in Taiwan from two intact reading classes participated in this study. They were divided into a paper-based group or an online reading instructional module group. Both groups received comparable reading strategy instruction. Results showed that the online reading group outperformed the paper-based group on overall reading comprehension.

Tuncer \& Bahad (2014) examined the effect of screen reading and reading from printed out material on student success and permanency in Introduction to Computer Lesson was 
investigated. The sample of the study was 78 freshman students registered in Erzincan University Refahiye Vocational School Post Service department. They were divided into control and experimental group. It was found that there is no significant difference between control and experiment groups. Furthermore, dual effect of applied method and gender on posttest scores and delayed test scores was insignificant. Results of the studies show that reading from printed out material is more efficient than screen reading.

Strategy instruction has proven valuable in enhancing reading comprehension skills of students at all levels. It was suggested that internet raises motivation among EFL learners and also encourages them to select and use proper strategies for comprehending written text.

\section{Self- Regulation}

According to educational psychology one synonym of self regulation is autonomy. According to (VandenBos, 2015; 985) selfregulation in educational psychology could be defined as "the control of one's behavior through the use of self-monitoring (keeping a record of behavior), self-evaluation (assessing the information obtained during selfmonitoring), and self-reinforcement (rewarding one- self for appropriate behavior or for attaining a goal)."

Ranalli (2013) study designed web-based and second language (L2) instructional resource called VVT (Virtual Vocabulary Trainer) to teach integrated vocabulary depth of knowledge and dictionary referencing skills to tertiary-level learners of English as a Second Language (ESL). It also evaluated the potential of online resources to address long-standing challenges in the field of L2 strategy instruction. Participants were 64 Mandarin Chinese university students at Iowa State University. The findings provided evidence of the feasibility of automated, online strategy instruction for complementing teacher led forms, while also shedding light on the challenges many L2 learners face in self-directed learning of vocabulary depth of knowledge. Finally, it demonstrated the potential of an integrative, multicomponential model of self-regulation for researching and theorizing about L2 learning.

Liu, Lan \& Ho (2014) study employed a Web-based tool, Google Docs, to determine the effects of Webbased collaboration on vocabulary improvements among learners of English as a foreign language (EFL). Participants in this study were 210 first- and second-year private university students in northern Taiwan. The findings of the study suggested that collaboration using a Web-based tool affects vocabulary knowledge development than passive collaboration. It was concluded that teachers need to understand students types of employment of vocabulary strategies learning new vocabulary words in o outside the classroom. This can enable teachers to support their students with how to employee new strategies to regulate their strategic processing. Finally, web-based 
learning participates in raising students motivation and interest towards the target language which increase students autonomy while learning.

The relationship between selfregulated learning strategies and students' language proficiency and reading comprehension was studied by Abbasian \& Hartoonianl (2014). Participants of this study were 115 MA (60) and BA (55) students of Islamic Azad University. Results revealed that there is a significant relationship between the students' use of self-regulated learning strategies and their language proficiency. Also, a significant relationship between the students' use of self-regulated learning strategies and their reading comprehension was found.

Jafarigohar \& Morshedian (2014) examined the effect of selfregulation instruction to the intermediate EFL readers on their ability to make within-text inferences. Fifty two EFL Iranian students in an English language institute participated in this study. They were divided in to control and experimental groups. The results showed that the experimental group outperformed the control group on the post-test of EFL reading comprehension, particularly in term of within-text inferencing.

Maftoon \& Tasnimi (2014) investigated the effect of selfregulation on EFL learners' reading comprehension. The study sample consisted of 149 Iranian EFL language learners studying at Islamic Azad Universities of Qazvin and Tehran. They were randomly divided into control and experimental group. The experimental group received direct teaching along with task-based instruction on self-regulation in reading in ten sessions. The results showed that self-regulation had a significant effect on reading comprehension of Iranian EFL learners.

\section{Vocabulary Strategies}

Strategy instruction for vocabulary acquisition in the computer-assisted environment helps learners become more effective learners, by individualizing the language learning experience and raising the awareness of strategies which they can use to learn on their own after they leave the language classroom. Shams (2013) admitted that internet is one product of technology. The world wide web facilitate learning as everything is available with fingertip. The learner can access and communicate widely and easily which create an autonomous self directed learner. This self-direction is essential in active development of learners' abilities empowering EFL learners with a wide range of strategies and making conditions for fostering their autonomy in learning vocabulary.

Bytheway (2011) main aim study was to explain and identify vocabulary learning strategies used by players in MMORPGS (massively multiplayer on- line role - player games), an informal second languages learning context. (Gu's 2005) model of 
vocabulary learning strategies was adopted to suit this MMORPGS second language learning context. It was resulted that vocabulary learning strategies in MMORPGS are affected by play, which affect learning process and motivation; MMORPG culture, which affects participants: interaction, curiosity, and independent learning; and the range and use of language in MMORP, which affects participants' language use, attitudes, and vocabulary learning strategies.

Heidari, Karimi \& Imani (2012) examined the effect of vocabulary learning strategy instruction on ESP vocabulary achievement and reading comprehension. Participants were sixty-six of Islamic Azad University students of Dareshahr majoring in Accounting, they were divided into control and experimental groups. The result showed that vocabulary learning strategy instruction had positive impact on ESP vocabulary achievement and reading comprehension of students. Cognitive strategies are the most frequent strategies employed by students in experimental group.

Ádám (2013) study aimed to investigate the influence factors like learning strategies and styles have on vocabulary acquisition. Participants were 241 students in the full-time BA English program Institute of English Studies in Pécs. Data analysis showed that the students' average vocabulary size is not exceptionally good, but it is indeed above the national average. The study concluded that there are some very beneficial styles and strategies, whereas methods might slow down vocabulary acquisition.

Dolgunsöz (2016) investigated the familiarity of word inference strategy on reading, inferences efficiency upon reading and different level of word knowledge, and lexical inferences upon reading rate and second pass rate. Seventy two EFL students in an ELT department participated in this study. Their age ranged from 19 to 22 years old. The study resulted in inferening correctly was significant with vocabulary knowledge and reading proficiency. Additionally inferencing strategy slower reading rate and second pass time. But correct inference rate and learning gains were significant.

In the light of the above discussion that made clear the importance of reading comprehension and the viable role of online selfregulation strategy instruction and vocabulary strategy instruction online, the present study aimed at investigating the impact of online selfregulation based vocabulary learning program to improve secondary stage EFL students reading comprehension skills.

\section{Pilot Study:}

In order to investigate the students present level in reading comprehension the researcher developed a reading comprehension test. The test aimed at measuring students reading comprehension skills through : 
Skill 1: Measuring students ability to identify new vocabulary.

* Skill 2: Measuring students ability to identify specific information.

- Skill 3: Measuring students ability to make generalizations.

The test was administered to a random sample of 25 female students. This sample was drawn from Ashraf Gawesh Secondary School in Nabarouh. The results are shown in table (1).

Table (1) Mean, percentage, and standard deviation of students score in the pilot study $(\mathrm{N}=25)$.

\begin{tabular}{|c|c|c|c|}
\hline Test Item & Mean & $\begin{array}{c}\text { Comprehension } \\
\text { Percentage }\end{array}$ & Std.Deviation \\
\hline $\begin{array}{c}\text { Measuring students ability to } \\
\text { identify new vocabulary }\end{array}$ & 1.8 & $30 \%$ & 1.3 \\
\hline $\begin{array}{c}\text { Measuring students ability to } \\
\text { identify specific information }\end{array}$ & 3.6 & $26 \%$ & 2.4 \\
\hline $\begin{array}{c}\text { Measuring students ability to make } \\
\text { generalizations }\end{array}$ & 1.6 & $32 \%$ & 1.3 \\
\hline Total & $\mathbf{7 . 0 4}$ & $\mathbf{2 8 \%}$ & $\mathbf{4 . 5}$ \\
\hline
\end{tabular}

Results in table (1) indicate that the sample mean scores percentages in the pilot study test were ( $30 \%$, $26 \%, 32 \%, 28 \%$ ) respectively and that all of them are below the acceptable level, which is around $50 \%$. This shows that the students' level in reading comprehension is rather low.

\section{- Statement of the problem}

Based on the review of literature and related studies and on a pilot study, the problem of the present study can be stated as follows: " Secondary stage students' level in reading comprehension is weak ". Therefore, the present study investigated how to improve students ' level of reading comprehension through an online self-regulation based vocabulary learning program.

\section{Research questions:}

The study attempts to answer the following questions:

1. What are the appropriate online reading comprehension skills to EFL 1st grade secondary school students?

2. What are the appropriate online vocabulary strategies that EFL 1st grade secondary school students can be trained in?

3. What are the appropriate online self regulation strategies that EFL 1st grade secondary school students can be trained in?

4. What are the components of an online self regulation based vocabulary learning program to develop the students' reading comprehension skills?

5. What is the impact of a proposed 
online self regulation based vocabulary learning program on developing reading comprehension skills of EFL 1st grade secondary school students?

\section{Hypotheses of the study:}

The hypotheses of the study stated as follows:

1. There is a statistically significant difference at the 0.01 level between the mean score of the control group and the experimental group on the post administration of the Online Reading Comprehension Test in favor of the experimental group due to implementing of the Proposed Online Self regulation Based Vocabulary Learning Program.

2. There is a statistically significant difference at the 0.01 level between the mean score of the experimental group in the prepost- administration of the Online Reading Comprehension Test in favor of post-administration due to the implementation of the Proposed Online Self regulation Based Vocabulary Learning Program.

3. There is no statistically significant difference at the 0.01 level between the mean score of the control group students in the pre and post-administration of the Online Comprehension Test.

\section{The Purpose of the Study}

The present study aims at:

1. Identifying online reading comprehension skills of EFL 1st grade secondary school students in an online context.

2. Designing an online self regulation based vocabulary learning program to develop 1st grade secondary school students' reading comprehension skills.

3. Developing 1 st grade secondary school students' use of selfregulation strategies.

4. Identifying necessary online vocabulary strategies that EFL 1 st grade secondary school students can use.

\section{The Significance of the Study:}

The present study contributed to:

1. Providing the ministry of education, teachers and researchers with an on line vocabulary learning program that may be useful in developing students' reading comprehension.

2. Providing teacher and curriculum designers with list of the reading comprehension skills in an online context of EFL 1st grade secondary school students.

3. Enriching curriculum with lists of some self-regulating strategies that may be useful in developing students reading comprehension skills.

4. Raising the awareness of curriculum designers of using online vocabulary strategies.

\section{Delimitations of the Study:}

The present study was limited to:

1. A random sample of 1 st grade secondary school students.

2. Some reading comprehension skills in an online context 
appropriate to 1 st grade secondary school students.

3. Some self-regulation strategies appropriate to a sample of $1 \mathrm{st}$ grade secondary school students.

4. Some online vocabulary strategies appropriate to a sample of 1 st grade secondary school students.

\section{Methodology:}

\section{Participants :}

The participants of the study were a random sample of 1st grade secondary school students which consisted of 60 students from Bahbeet Alhegara Secondary school in Samnoud Educational Zone. They were divided into an experimental group which consisted of 30 students and a control group which consisted of 30 students.

\section{Design:}

The study adopted both descriptive analytical and quasi experimental designs. First, the descriptive approach was used to identify the reading comprehension sub skills, online vocabulary strategies, and online self regulating strategies suitable for students level and the aim of this research. Second, the quasi experimental approach was used to administer the proposed online self regulation based vocabulary learning program to the experimental group students.

\section{Instruments:}

The following instrument were designed by the researcher:

1. An online reading comprehension skills questionnaire in order to construct a reading comprehension skills test and the proposed online self regulation based vocabulary learning program .

2. An online reading comprehension test as a pre-and post-test in order to measure the participants' reading comprehension skills level pre- and post- administering the program.

3. An online self-regulation strategies scale order to identify some suitable online self regulation strategies to the first grade secondary grade students to construct the suggested online self regulation based vocabulary learning program .

4. An online vocabulary learning strategies inventory in order to identify the appropriate online vocabulary learning strategies to the first grade secondary grade students to construct the suggested online self regulation based vocabulary learning program .

\section{Definition of terms: \\ Vocabulary:}

For the purpose of the current study and in the light of (Pikulski \& Templeton, 2004; Williamson, 2014) vocabulary will be defined as: a list of words, figures of speech, or technical terms that is considered new or unfamiliar to 1st grade secondary school students, these vocabulary items are studied through on line self regulation strategies in order to improve students reading comprehension skills. 


\section{Reading Comprehension}

For the purpose of the current study (Mehndiratta, 2002:771) definition will be adopted: "The extent to which an individual understands material that has been read and is able to recall both such meaning and factual details of reading; such capabilities are evaluated in a reading comprehension test".

\section{Self Regulation}

For the purpose of the current study and in the light of (Zimmerman, 2002; Zimmerman, 2000 cited in Bembenutty, 2011) self regulation will be defined as: "learner's belief and use of cognitive, metacognitive, behavioral strategies and motivational elements in academic situation for achieving proposed goals in order to generate the use of such strategies and elements in another situations in or outside the classroom.

\section{Online Learning}

For the purpose of the current study and in the light of (Michigan Merit Curriculum Guidelines, 2006; Watson, Winograd \& Kalmon, 2004cited in Cavanaugh, Barbour \& Clark,
2009; Brewer, DeJonge \& Stout, 2001) online learning will be defined as: asynchronous interaction between the learner and the computer through liner steps such as glossing and inferring new vocabularies in a hypertext in order to develop the students` reading comprehension skills.

\section{Results and Discussion}

The results of the study are statistically analyzed in terms of its hypotheses and they are discussed in the light of the theoretical background and related studies. Results of the study were reported as follows.

Hypothesis \#1: "There is a statistically significant difference at the 0.01 level between the mean score of the control group and the experimental group on the post administration of the Online Reading Comprehension Skills Test in favor of the experimental group due to implementing of the proposed online self regulation based vocabulary learning program." To verify hypothesis \#1 the researcher used the t-test for independent samples. See table (2). 
Table (2) Comparing the mean score of the experimental group and that of the control group on the post administration of the online reading comprehension test.

\begin{tabular}{|c|c|c|c|c|c|c|}
\hline Skill & \multicolumn{2}{|c|}{$\begin{array}{c}\text { Experimental } \\
\text { Group (N=30) }\end{array}$} & \multicolumn{2}{c|}{$\begin{array}{c}\text { Control Group } \\
\text { (N=30) }\end{array}$} & $\begin{array}{c}\text { T- } \\
\text { Value }\end{array}$ & Significance \\
\hline Mean & $\begin{array}{c}\text { Standard } \\
\text { Deviation }\end{array}$ & Mean & $\begin{array}{c}\text { Standard } \\
\text { Deviation }\end{array}$ & & \\
\hline $\begin{array}{c}\text { Predicting what is the } \\
\text { writer is going to talk } \\
\text { about through attached } \\
\text { pictures and the title. }\end{array}$ & 3.13 & 1.13 & 1.60 & 1.61 & 4.26 & 0.01 \\
\hline $\begin{array}{c}\text { Guessing the meaning } \\
\text { of the new word from } \\
\text { an online context. }\end{array}$ & 2.73 & 1.11 & 0.86 & 1.25 & 6.10 & 0.01 \\
\hline $\begin{array}{c}\text { Inferring information } \\
\text { from online text. }\end{array}$ & 2.40 & 1.22 & 0.73 & 1.22 & 5.26 & 0.01 \\
\hline $\begin{array}{c}\text { Recognizing writer`s } \\
\text { purpose attitude, tone } \\
\text { and mode in an online } \\
\text { text. }\end{array}$ & 2.33 & 1.29 & 0.800 & 1.12 & 4.89 & 0.01 \\
\hline $\begin{array}{c}\text { Skimming online text } \\
\text { to understand the gist. }\end{array}$ & 2.53 & 1.27 & 1.00 & 1.01 & 5.13 & 0.01 \\
\hline $\begin{array}{c}\text { Scanning online text to } \\
\text { understand relevant } \\
\text { details. }\end{array}$ & 2.40 & 1.22 & 0.93 & 1.25 & 4.58 & 0.01 \\
\hline $\begin{array}{c}\text { Distinguishing fact } \\
\text { from opinion. }\end{array}$ & 2.13 & 1.47 & 0.733 & 1.33 & 3.84 & 0.01 \\
\hline $\begin{array}{c}\text { Making predictions } \\
\text { based on the title, } \\
\text { subtitles schema and } \\
\text { figures within an } \\
\text { online text. }\end{array}$ & 2.06 & 1.33 & 0.46 & 1.00 & 5.23 & 0.01 \\
\hline $\begin{array}{c}\text { Reducing online text } \\
\text { by rejecting redundant } \\
\text { or irrelevant items. }\end{array}$ & 2.33 & 1.06 & 0.73 & 1.11 & 5.70 & 0.01 \\
\hline $\begin{array}{c}\text { Reading at an efficient } \\
\text { rate of speed to suit the } \\
\text { purpose. }\end{array}$ & 1.60 & 1.22 & 0.40 & 0.96 & 4.21 & 0.01 \\
\hline Total & $\mathbf{2 3 . 6}$ & $\mathbf{7 . 2 9}$ & $\mathbf{8 . 6}$ & $\mathbf{7 . 6 9}$ & $\mathbf{7 . 9 2}$ & $\mathbf{0 . 0 1}$ \\
\hline
\end{tabular}

Table (2) reports that the Tvalues were $(4.26,6.10,5.26,4.89$, $5.13,4.58,3.84,5.23,5.70,4.21,7.92$ respectively) and that all of them were statistically significant at (0.01). This means that there were significant differences between the experimental and the control groups in the postadministration of the Online Reading Comprehension Test. This also signifies that the proposed online self regulation based vocabulary learning program had its effect on each reading comprehension skill online and on the total score of the test as a whole. Therefore, the first hypothesis of the study is verified and accepted.

Hypothesis \#2: "There is a statistically significant difference at the 0.01 level between the mean score of the experimental group in the prepost- administration of the Online 
Reading Comprehension Test in favor of post-administration due to the implementation of the proposed online self regulation based vocabulary learning program."

T-test for dependent samples between the mean score of the experimental group students in the online reading comprehension test before and after administering the proposed online self regulation based vocabulary learning program.

was used to compare the difference

Table (3) Differences between the mean score of the experimental group students on the pre-post administration of the online reading comprehension test.

\begin{tabular}{|c|c|c|c|c|c|c|c|}
\hline \multirow[t]{2}{*}{ Skill } & \multicolumn{2}{|c|}{$\begin{array}{l}\text { Experimental Group } \\
\text { Pre-Administration }\end{array}$} & \multicolumn{2}{|c|}{$\begin{array}{l}\text { Experimental } \\
\text { Group Post- } \\
\text { Administration } \\
\end{array}$} & \multirow{2}{*}{$\begin{array}{c}\text { T- } \\
\text { Value }\end{array}$} & \multirow[t]{2}{*}{ Significance } & \multirow[t]{2}{*}{$\mathrm{Eta}^{2}$} \\
\hline & Mean & $\begin{array}{c}\text { Standard } \\
\text { Deviation } \\
\end{array}$ & Mean & $\begin{array}{c}\text { Standard } \\
\text { Deviation } \\
\end{array}$ & & & \\
\hline $\begin{array}{l}\text { Predicting what is } \\
\text { the writer is going } \\
\text { to talk about } \\
\text { through attached } \\
\text { pictures and the } \\
\text { title. }\end{array}$ & 1.20 & 1.62 & 3.13 & 1.13 & 6.92 & 0.01 & 0.62 \\
\hline $\begin{array}{l}\text { Guessing the } \\
\text { meaning of the new } \\
\text { word from an online } \\
\text { context. }\end{array}$ & 0.800 & 1.24 & 2.73 & 1.11 & 7.91 & 0.01 & 0.68 \\
\hline $\begin{array}{c}\text { Inferring } \\
\text { information from } \\
\text { online text. }\end{array}$ & 0.73 & 1.11 & 2.40 & 1.22 & 7.04 & 0.01 & 0.63 \\
\hline $\begin{array}{c}\text { Recognizing } \\
\text { writer's purpose } \\
\text { attitude, tone and } \\
\text { mode in an online } \\
\text { text. } \\
\end{array}$ & 1.00 & 1.36 & 2.33 & 1.29 & 5.52 & 0.01 & 0.51 \\
\hline $\begin{array}{l}\text { Skimming online } \\
\text { text to understand } \\
\text { the gist. }\end{array}$ & 1.20 & 1.44 & 2.53 & 1.27 & 4.81 & 0.01 & 0.44 \\
\hline $\begin{array}{l}\text { Scanning online text } \\
\text { to understand } \\
\text { relevant details. }\end{array}$ & 1.40 & 1.49 & 2.40 & 1.22 & 3.34 & 0.01 & 0.27 \\
\hline $\begin{array}{l}\text { Distinguishing fact } \\
\text { from opinion. }\end{array}$ & 1.20 & 1.12 & 2.13 & 1.47 & 3.50 & 0.01 & 0.29 \\
\hline $\begin{array}{l}\text { Making predictions } \\
\text { based on the title, } \\
\text { subtitles schema } \\
\text { and figures within } \\
\text { an online text. }\end{array}$ & 0.800 & 0.99 & 2.06 & 1.33 & 5.64 & 0.01 & 0.52 \\
\hline $\begin{array}{l}\text { Reducing online } \\
\text { text by rejecting } \\
\text { redundant or } \\
\text { irrelevant items. }\end{array}$ & 1.00 & 1.25 & 2.33 & 1.06 & 6.02 & 0.01 & 0.55 \\
\hline $\begin{array}{l}\text { Reading at an } \\
\text { efficient rate of } \\
\text { speed to suit the } \\
\text { purpose. }\end{array}$ & 0.46 & 0.86 & 1.60 & 1.22 & 5.46 & 0.01 & 0.50 \\
\hline Total & 9.800 & 9.17 & 23.6 & 7.29 & 12.31 & 0.01 & 0.83 \\
\hline
\end{tabular}


Results in table (3) reveal that the mean score in the postadministration of the Online Reading Comprehension Test was greater than that of the pre-administration in all online reading comprehension subskills.

\section{The above table reports that:}

1. T-test value was significant at (0.01) for the mean of the ten reading comprehension subskills and the mean of the total score of whole online reading comprehension test (6.92, 7.91, 7.04, 5.58, 4.81, $3.34,3.50,5.64,6.02,5.46$, 12.31 respectively). All differences were in favor of the post-administration of the online reading comprehension test.

2. The Effect Size was calculated as $(0.83)$ which means that $(83 \%)$ of the variance in the total dependent variable could be ascribed to the effectiveness of the proposed online self regulation based vocabulary learning program (among other variables not included in the current study such as private tutoring, school environment, etc) .

It is, thus, evident that the training program made a great difference in the use of the reading comprehension skills online for the experimental group. Therefore, the second hypothesis of the study is verified and accepted.

Hypothesis \#3: " There is no statistically significant difference at the 0.01 level between the mean score of the control group students in the pre and post-administration of the Online Reading Comprehension Test."

T-test for dependent samples was used to compare the difference between the mean score of the control group students in the online reading comprehension before and after administering the Proposed Online Self regulation Based Vocabulary Learning Program. 
Table (4) Differences between the mean score of the control group pre- postadministration of the.

\begin{tabular}{|c|c|c|c|c|c|c|}
\hline \multirow[t]{2}{*}{ Skill } & \multicolumn{2}{|c|}{$\begin{array}{c}\text { Control Group } \\
\text { Pre- } \\
\text { Administration } \\
\end{array}$} & \multicolumn{2}{|c|}{$\begin{array}{l}\text { Control Group } \\
\text { Post- } \\
\text { Administration }\end{array}$} & \multirow{2}{*}{$\begin{array}{c}\text { T- } \\
\text { Value }\end{array}$} & \multirow[t]{2}{*}{ Significance } \\
\hline & Mean & $\begin{array}{c}\text { Standard } \\
\text { Deviation }\end{array}$ & Mean & $\begin{array}{l}\text { Standard } \\
\text { Deviation }\end{array}$ & & \\
\hline $\begin{array}{l}\text { Predicting what is the } \\
\text { writer is going to talk } \\
\text { about through attached } \\
\text { pictures and the title. }\end{array}$ & 1.53 & 1.63 & 1.60 & 1.61 & 1.00 & No Sig. \\
\hline $\begin{array}{c}\text { Guessing the meaning of } \\
\text { the new word from an } \\
\text { online context. }\end{array}$ & 1.00 & 1.36 & 0.86 & 1.25 & 1.43 & No Sig. \\
\hline $\begin{array}{l}\text { Inferring information from } \\
\text { online text. }\end{array}$ & 0.866 & 1.25 & 0.73 & 1.22 & 1.43 & No Sig. \\
\hline $\begin{array}{l}\text { Recognizing writer`s } \\
\text { purpose attitude, tone and } \\
\text { mode in an online text. }\end{array}$ & 0.800 & 1.12 & 0.800 & 1.12 & 1.33 & No Sig. \\
\hline $\begin{array}{l}\text { Skimming online text to } \\
\text { understand the gist. }\end{array}$ & 0.93 & 1.01 & 1.00 & 1.01 & 1.00 & No Sig. \\
\hline $\begin{array}{l}\text { Scanning online text to } \\
\text { understand relevant } \\
\text { details. }\end{array}$ & 1.00 & 1.36 & 0.93 & 1.25 & 1.00 & No Sig. \\
\hline $\begin{array}{l}\text { Distinguishing fact from } \\
\text { opinion. }\end{array}$ & 0.73 & 1.33 & 0.733 & 1.33 & 1.23 & No Sig. \\
\hline $\begin{array}{l}\text { Making predictions based } \\
\text { on the title, subtitles } \\
\text { schema and figures within } \\
\text { an online text. }\end{array}$ & 0.46 & 1.00 & 0.46 & 1.00 & 1.21 & No Sig. \\
\hline $\begin{array}{l}\text { Reducing online text by } \\
\text { rejecting redundant or } \\
\text { irrelevant items. }\end{array}$ & 0.73 & 1.11 & 0.73 & 1.11 & 1.11 & No Sig. \\
\hline $\begin{array}{l}\text { Reading at an efficient } \\
\text { rate of speed to suit the } \\
\text { purpose. }\end{array}$ & 0.600 & 1.06 & 0.40 & 0.96 & 1.79 & No Sig. \\
\hline Total & 8.66 & 7.86 & 8.6 & 7.69 & 1.53 & No Sig. \\
\hline
\end{tabular}

Table (4) reports that the $\mathrm{T}$ values were $(1.00,1.43,1.43,1.33$, $1.00,1.00,1.23,1.21,1.11,1.79,1.53$ respectively) and that all of them were statistically not significant. This means that there were no significant differences between the pre and post administration of the online reading comprehension skills test to the control group within in mean of all reading comprehension subskills online and the mean of the total score of the online reading comprehension test. Therefore, the third hypothesis of

the study is verified and accepted.

\section{Conclusion}

Based on the statistical analysis of the study results and the discussion mentioned above, it can be concluded that using online self regulation based vocabulary learning program improves EFL secondary stage students reading comprehension skills.

\section{Recommendations of the Study:}

Based on the results and conclusions of this study, the 
following recommendations are suggested:

1. Ministry of Education should train EFL students on the use new technology; computer skills and online program are included, in order to help their students to interact in an authentic environment and learn English language skills more independently and effectively.

2. Apart of teaching the four language skills should be conducted online because it is a demand for this age to practise theses skills online while preparing students to go in their daily life .

3. New techniques of integrating various strategies of teaching vocabulary should be integrated while designing EFL curriculum as well as the four language skills.

4. Reading skill should be taught differently because traditional textbook teaching is no longer appropriate in the age of internet. Students should be trained in comprehending the written text online.

\section{References}

Abbasian, G. \& Hartoonian1, A. (2014). Using Self-Regulated Learning Strategies in Enhancing Language Proficiency with a Focus on Reading Comprehension. English Language Teaching, 7(6), 160-167.

Ádám, L. (2013). The Importance of Strategies in EFL Vocabulary
Acquisition. Available at: https://www. academia. edu/3191919/The

_Importance_of_Strategies_in $\bar{V}$ ocabulary_Acquisition. $E \bar{F} L$ Retrieved November, 11, 2014 at10.00 P.M.

Al-Asmari, A. \& Ismail, N. (2012). Self-Regulated Learning Strategies as Predictors of Reading Comprehension among Students of English as a Foreign Language. International Journal of Asian Social Science, 2 (2), 178-201.

Bembenutty, H. (2011). Introduction: Self-Regulated of Learning of Learning in Postsecondary Education. New Directions for Teaching and Learning, 2011( 126), 1-124.

Brewer, E. , DeJonge, J. \& Stout, V. (2001). Moving to Online. Making the Transition from Traditional Instruction and Communication Strategies. Thousand Oaks, CA: Corwin Press, Inc.

Bytheway, J. (2011). Vocabulary learning strategies in Massively Multiplayer online Role playing Games. Unpublished MA Thesis, Victoria University of Wellington.

Cavanaugh, C. Barbour,M. \& Clark,T.(2009). Research and Practice in K-12 Online Learning: Review of Open Access Literature. International Review of Research in Open 
and Distance Learning: 10( 1), 1492-3831.

Chen, H. (2009). Online Reading Comprehension Strategies Among General And Special Education Elementary And Middle School Students. Eric Reproduction Services, ED506429.

Clark, M. (2013). The Use of Technology to Support Vocabulary Development of English Language Learners. Unpublished MA Thesis, St. John Fisher College.

Constantinescu, A. et al. (2007). Using Technology to Assist in Vocabulary Acquisition and Reading Comprehension. The Internet TESL Journal, XIII (2).

Davis, S. \& Gray, E. (2007). Going Beyond Test-Taking Strategies: Building Self-Regulated Students and Teachers. Journal of Curriculum and Instruction , $1(1)$.

Dolgunsöz, E. (2016). Using EyeTracking to Measure Lexical Inferences and Its Effects on Reading Rate during EFL Reading. Journal of Language and Linguistic Studies, 12 (1), 63-78.

Elangovan, S. \& Chia, N. (2013). An Inter - correlation study of the reading components in profiling and Generating a cognitive equation for reading performance of students with Autism. International Journal of special Education, 28 (2), 17 35.
Fleet, A. (1999). Basic Vocabulary Instruction. In Laviy, A.(Ed). International Encyclopedia of Curriculum. Israel, Pergaman Press.

Hamedani, S. (2013). The Relationship between SelfEfficacy and Self-Regulation in Vocabulary Acquisition of Iranian EFL Learners. Journal of Academic and Applied Studies, 3(1), 20-31.

Heidari, L., Kalimi, F., \& Imani, A. (2012). Vocabulary Learning Strategy Instruction: It's Impact on English for Specific Purpose Vocabulary Achievement and Reading Comprehension. The Middle-East Journal of Scientific Research, 12 (11), 1488-1496.

Huang, H. (2014). Online Versus Paper-Based Instruction: Comparing Two Strategy Training Modules for Improving Reading Comprehension. Eric Reproduction Services, EJ1040037.

Jafarigohar, M. \& Morshedian, M. (2014). The Effect of SelfRegulation on Improving EFL Readers' Ability to Make Within-Text Inferences. Issues in Language Teaching, 3(2), 263-286.

James, P. (2012). Developing Self Regulated Reader. Available at:csuchiodespace.calstate.edu/handlel10 211.4/466. Retrieved January, 11th, 2014 at 05.55 PM. 
John J. \& Shane, T. (2004). Teaching and Developing Vocabulary: Key to Long-Term Reading Success. Available at: http://www.eduplace.com/state/ pdf/ author/pik_temp.pdf Retrieved December, 15, 2013 at 11.39 P.M.

Koren, S. (1999). Vocabulary Instruction through Hypertext: Are There Advantages over Conventional Methods of Teaching? TESL-EJ., 4(1), 114.

Lenhard, W. et al (2011). Rethinking Strategy Instruction: Direct Reading Strategy Instruction Versus Computer-Based Guided Practice. Journal of Research in Reading, 00(00), 1-18.

Liu, S., Lan, Y., \& Ho, C. (2014). Exploring the Relationship between Self - Regulated Vocabulary Learning and Web Based Collaboration. Educational Technology \& Society, 17(4), $404-419$.

Maftoon, P. \& Tasnimi, M. (2014). Using Self-regulation to Enhance EFL Learners' Reading Comprehension. Journal of Language Teaching and Research, (5), 4, 844-855.

Mehndiratta, M. (2002). Dictionary of Education. 3rd ed. New Delhi: KSP Aperbacks.

Michigan Merit Curriculum Guidelines, Online Experience, Michigan. Department of Education (2006). Available at: http://www.michigan.gov/docu ments/mde/Online10.06 final 175750_7.pdf. Retrieved

December, 15, 2013 at 11.36 PM.

Mohamed, H. (2010). Using Computer to Train Preparatory School Pupils on Some Learning Strategies for Developing their English Language Reading Comprehension. Unpublished MA Thesis, Damietta Faculty of Education.

Pikulski, J. \& Templeton, S. (2004). Teaching and Developing Vocabulary: Key to Long-term Reading Success. Available at:https://www.eduplace.com /marketing/nc/pdf/author pages.pdf. Retrieved October, 22nd, 2014 at 08:46 PM.

Ranalli, J. (2013). Online Strategy Instruction for Integrating Dictionary Skills and Language Awareness. Language Learning and Technology, 17 (2), 75-99.

Shams, I. (2013). Hybrid Learning and Iranian EFL Learners' Autonomy in Vocabulary Learning. Procedia - Social and Behavioral Science, 93, 15871592.

Tuncer, M. \& Bahad, F. (2014). Effect of Screen Reading and Reading from Print out Material on Students Success and Permanency in Introduction to Computer Lesson. Turkish Online Journal of Educational Technology, 13(3), July, 41-49.

VandenBos, G. (2015). APA dictionary of psychology. 2nd 
ed. Washington, DC: American Psychological Association.

Williamson, G. (2014). Vocabulary. Available at: com/vocabulary /. Retrieved December , 15, 2013 at $11.36 \mathrm{PM}$.

Woolley, G. (2011). Reading Comprehension: Assisting Children with Learning Difficulties. Available at: https://link. $\quad$ springer.com /content /pdf/ 10.1007\%2F97894-007-1174-7. pdf. Retrieved January, 11th, 2014 at 05.55 PM.

Zimmerman, B. (2002). Attaining Self regulation. In Boekaerts, M., Pintrich, P., \& Zeidner, M. A. The Hand book of Self Regulation. USA: Library of Congress (13-41). 